\title{
IMPACT OF COVID-19 ON TRANSPORTATION SYSTEM OF INDIA
}

\section{DIVYESH PATEL ${ }^{1}$, DR. DILIP R. VAHONIYA ${ }^{2}$, DR. PRAKASHKUMAR HASMUKHBHAI PATEL ${ }^{3}$ \& NIHARIKA SHAH ${ }^{4}$}

${ }^{I}$ Scholar (Dharmsinh Desai University), Assistant Professor, C K Shah Vijapurwala Institute of Management, Vadodara, Gujarat, India

${ }^{2}$ Assistant Professor \& Head, Agri-Entrepreneurship and Project Management - (Department Faculty), International Agribusiness Management Institute, Anand Agricultural University, Anand, Gujarat, India

${ }^{3}$ Assistant Professor, Department of Commerce and Business Management, Faculty of Commerce, The Maharaja Sayajirao University of Baroda, Vadodara, Gujarat, India

${ }^{4}$ Data Processing Specialist, Nielsen India, Vadodara, Gujarat, India

\begin{abstract}
The aim of this paper is to study the impact of COVID-19 on Transportation system of India. Exploratory research designed has been used and secondary data have been collected from various external sources to study the impact on Road, Railway and Aviation in India. All public transportation services had been called off by the Union Government till further notices. The corona virus pandemic has a significant impact on Road, Railway and aviation as a result of restrictions imposed by Government on travel as well as due to fall in demand among the travellers they will face huge loss. As a result to this most of the airlines are collapsing without any substantial government intervention. No past research has discovered the Impact of COVID-19 on Indian Transportation System. Future research will be carried out based on the findings of this study. KEYWORDS: Centre for Aviation (CAPA), Corona, Outbreak, COVID-19, Pandemic, Transportation \& World Health Organization (WHO)
\end{abstract}

Received: May 21, 2020; Accepted: Jun 11, 2020; Published: Jul 30, 2020; Paper Id.: IJMPERDJUN2020538

\section{INTRODUCTION}

With an intensive ability to spread and cause serious illness, corona virus has prompted major countries to plan or introduce extensive public health. Symptoms shown by corona infected person are - severe cough, high fever and shortness of breath. Corona virus is a contagious virus which can be easily spread form one person to other. Corona spreads through sneeze or cough of the infected person. When the infected person sneeze or cough, the droplets are formed which enter the nose or mouth of the non-infected person or even it can reach to the lungs of the non-infected person. Another way the virus is spread is when infected person sneeze or cough, the droplets may fall on few objects or surfaces and when the non-infected person touches object or surface and then to his/her mouth or nose might get the infections. ${ }^{1}$ COVID-19 can live on common surfaces at $21^{\circ} \mathrm{C}$ to $23^{\circ} \mathrm{C}$ along with $40 \%$ relative humidity. ${ }^{2}$

\footnotetext{
${ }^{1}$ https://www.theguardian.com/world/2020/apr/01/what-is-coronavirus-and-what-is-the-mortality-rate-covid-19 last retrieved on 26.03.2020

${ }^{2}$ https://www.businessinsider.in/science/news/one-graphic-shows-how-long-the-coronavirus-lives-on-surfaces-likecardboard-plastic-and-steel/articleshow/74720814.cms last retrieved on 26.03.2020
} 
Table 1: Lifespan of covid-19 on Common Surface

\begin{tabular}{|l|l|}
\hline \multicolumn{1}{|c|}{ Surface } & \multicolumn{1}{c|}{ Lifespan of Covid-19 } \\
\hline Air & 3 hours \\
\hline Copper & 4 hours \\
\hline Cardboard & 24 hours \\
\hline Stainless steel & $2-3$ days \\
\hline Polypropylene plastic & 3 days \\
\hline $\begin{array}{l}\text { Source: } \text { https://www.businessinsider.in/science/news/one-graphic- } \\
\text { shows-how-long-the-coronavirus-lives-on-surfaces-like-cardboard- } \\
\text { plastic-and-steel/articleshow/74720814.cms }\end{array}$ \\
\hline
\end{tabular}

\subsection{Impact of COVID-19 on Various Industries}

As stated in one of the report, the sectors which are going to be worst affected due to corona virus are - Construction, transport and Chemical manufacturing. Notwithstanding, India's top imports raw petroleum and diamonds and adornments which on the whole record for 46 percent of all out imports are moderately insulated from the general wellbeing emergency in China, as indicated by the report by ICICI Securities. ${ }^{3}$

India has total import of USD 507 billion if FY19, out of which 26 percent comprises of iron, steel and inorganic chemicals. This will be moderately affected as India is importing 11 percent of its iron and steel from China. Also, South Korea which is the biggest import source country for India imports 20 percent of its requirement from China. Corona virus will also have moderate impact on Inorganic chemicals as India imports 15 percent of it from China. Import of Electrical Machinery, Mechanical apparatuses, Organic synthetic compounds, Plastics and Optical and surgical instruments vigorously rely upon China and its almost 28 percent of India's import. ${ }^{4}$

\subsection{Economic and Social Impact}

The International Road Transport Union (IRU) is representing the 3.5 million vehicle working organizations, is checking the circumstance over the globe cautiously and assessing the pandemic's effects on business street transport. About $6 \%$ of the people worldwide are employed in road transport. Mostly they are employed with small and medium sized firms which will not be able to cope up easily with this pandemic due to their size.

\subsection{Estimated Economic Loses}

As per Barclays, the cost of the two shorter lock downs as well as the 21 days lockdown will be around $\square 8.5$ lakh crore (US\$120 billion).Moody's Investors Service downgraded its estimate of India's GDP growth for 2020 from $5.3 \%$ to $2.5 \% .^{5}$ Confederation of Indian Industry (CII) has sought an economic fiscal stimulus package of $1 \%$ of India's GDP amounting to $\square 2$ lakh crore (US\$28 billion) ${ }^{6}$. Jefferies Group said that the government can spend $\square 1.3$ lakh crore (US\$18 billion) to fight the impact of corona virus. ${ }^{7}$ Bloomberg's economists say at least $\square 2.15$

\footnotetext{
${ }^{3}$ https://economictimes.indiatimes.com/news/economy/foreign-trade/coronavirus-construction-transport-chemicalmanufacturing-likely-to-be-worst-affected-says-report/articleshow/74635122.cms?from=mdr last retrieved on 26.03.2020

${ }^{4}$ https://economictimes.indiatimes.com/news/economy/foreign-trade/coronavirus-construction-transport-chemicalmanufacturing-likely-to-be-worst-affected-says-report/articleshow/74635122.cms last retrieved on 26.03.2020

${ }^{5}$ https://economictimes.indiatimes.com/news/economy/indicators/moodys-slashes-india-gdp-growth-in-2020-to-25/articleshow/74840446.cms?from=mdr Retrieved on 28 March 2020

${ }^{6}$ https://economictimes.indiatimes.com/news/economy/policy/india-inc-seeks-fiscal-stimulus-moratorium-on-debtrepayment-to-mitigate-coronavirus-impact/articleshow/74759967.cms?from=mdr retrieved on 26 March 2020

${ }^{7}$ https://www.livemint.com/news/india/coronavirus-govt-can-spend-18-billion-to-fight-virus-impact-analysts-say11584949476261.html. Retrieved on 24 March 2020
} 
lakh crore (US\$30 billion) needs to be spent. $^{8}$ It is estimated that the loss to the tourism industry will be $\square 15,000$ crore (US\$2.1 billion) for March and April alone. CII, ASSOCHAM and FAITH estimate that a huge chunk of the workforce involved with tourism in the country faces unemployment. ${ }^{9}$

\section{METHODOLOGY}

The aim of this research is to study the Impact of COVID-19 on Transportation System of India. This study focused on Public transportation which includes Road, Rail and Aviation as public transportation is on high risk as the virus spreading in the human only. The research contains the exploratory design as it helps to assist to Impact of COVID-19 on Indian transportation System. Secondary data has been collected to derive the results regarding the impact of COVID-19 on Public transportation which includes Road transportation, Railway Transportation and Aviation (Airlines). The external data collected from various websites of Ministry of Government, News Papers, News Channel and material of various websites.

\section{RESULTS}

\subsection{Impacts to Transportation System in India}

As corona virus keeps on broadening, its impact is being caught up in each corner of the economy even the global supply chain has got no exception. Transportation makes the world smaller for us by creating a global network through movement of people and things.

The virus has been spread in a local-global-local transportation manner. Locally the virus is spreading via the physical interaction with the urban communities either via public transports or through social gatherings. People travelling from various foreign countries either by air or ships are spreading the virus. Locally again when the individual interacts with the contaminated one's. Transportation will be one of the most terribly affected sector due to corona virus pandemic. Transportation and logistics network is put on the test with the fall in manufacturing, exports and overall global commerce. $^{10}$

\subsection{Public Transportation}

Public transport systems can be viewed as a high risk environment because of large number of people in a restricted space with constrained ventilation. There is no control as one cannot recognize potentially sick persons. Even there are much common surfaces to touch on such as ticket machines or door knobs etc. Public transport is an essential service to provide mobility, also in times of pandemics, not least to provide access to health care facilities. ${ }^{\mathbf{1 1}}$

A met was organized in New Delhi by The Parliamentary Standing Committee on Transport, Tourism and Culture to analyse the impact of Corona virus on Railway as well as aviation sector. The Ministry of Civil Aviation has also shown

\footnotetext{
${ }^{8}$ https://www.livemint.com/news/india/coronavirus-govt-can-spend-18-billion-to-fight-virus-impact-analysts-say11584949476261.html Retrieved on 24 March 2020

${ }^{9}$ https://www.hindustantimes.com/india-news/nirmala-sitharaman-reviews-sectors-that-may-need-intervention/storyKhFNT5NejEDB4F3K8RPM0H.html retrieved on 25 March 2020
}

\footnotetext{
${ }^{10} \mathrm{https}: / /$ www.jdsupra.com/legalnews/covid-19-impacts-to-transportation-12356/ retrieved on 28 March 2020

${ }^{11}$ https://www.uitp.org/sites/default/files/cck-focus-papers-files/Corona\%20Virus_EN.pdf retrieved on 27 March 2020
} 
that the aviation industry is also facing enormous loss. ${ }^{12}$

\subsubsection{Road Transport}

While the full size of COVID-19 isn't yet known, we can just expect that the flare-up will proceed genuinely affecting the worldwide economy, exchange and the travel industry in the coming many months. The production and distribution of goods is reliant on road transport administrators. Based on the critical fall in intercontinental shipments, IRU gauges a decrease in worldwide road transport action of up to $20 \%$ in 2020 , contingent upon to what extent the circumstance proceeds. This could prompt a worldwide misfortune in administrator incomes of $\$ 800$ billion. $^{13}$

In India all means of road transport either it is bus or mini bus or maxi cabs or auto services or cab services had been called off by the Union Government till further notice (expected till $14^{\text {th }}$ April, 2020). The most important concern for road transporter is to keep functioning of supply chain of essential and clinical things in the most secure route as per most recent applicable government rules. ${ }^{14}$

\subsubsection{Ensure Smooth Supply of Essential Goods}

Commerce and Industry Minister held discussion, through video conference, with stakeholders from e-commerce and logistics industry on the issues faced by them due to COVID-19 (corona virus) lockdown and measures to resolve them. The meeting was attended by representatives of Snapdeal, Shopclues, Flipkart, Grofers, NetMeds, PharmEasy, 1MG Tech, Udaan, Amazon India, Big Basket, Zomato. Large retail operators were represented by Metro Cash \& Carry, Walmart, Delihivery, Safexpress, Paytm, and Swiggy. As a result of efforts made by the Department for Promotion of Industry and Internal Trade (DPIT), Ministry of Home affairs has issued standard operating procedure for state government's guidance on how to handle various aspects related to supply of essential goods. ${ }^{15}$

Cross boarder movement of fundamental merchandise needs to be open and keep transport joins open in influenced territories, with the goal that individuals and basic products can get to where they should be, and to secure vehicle labourers and organizations that are the financial spine of our society. ${ }^{16}$ To keep road transport systems working, The Reserve Bank of India (RBI) permitted all loaning organizations to offer a moratorium to borrowers on reimbursement of all term loans. ${ }^{17}$ The National Highways Authority of India (NHAI) will stop collecting toll charges across National during the 21 days' lockdown. ${ }^{18}$

\subsubsection{Railways}

\footnotetext{
${ }^{12}$ https://www.indiatoday.in/india/story/parliamentary-committee-reviews-impact-of-coronavirus-on-aviation-railways1657155-2020-03-18 retrieved on 29 March 2020

${ }^{13} \mathrm{http}: / / \mathrm{www}$.fruitnet.com/eurofruit/article/181164/road-supply-chains-must-keep-moving retrieved on $30 \mathrm{March} 2020$

${ }_{14}$ https://www.iru.org/system/files/IRU\%20open\%20letter\%20-

$\%$ 20Coronavirus $\% 20$ and $\% 20$ its $\% 20$ impact $\% 20$ on $\% 20$ supply $\% 20$ chains $\% 20$ and $\% 20$ mobility $\% 20$ networks.pdf retrieved on 26 March 2020

${ }^{15}$ https://economictimes.indiatimes.com/news/economy/policy/covid-19-regularly-engaging-with-e-retailers-traders-toensure-smooth-supply-of-essential-goods-says-dpiit/printarticle/74846292.cms retrieved on 29 March 2020

${ }^{16}$ https://www.iru.org/system/files/IRU\%20open\%20letter\%20-

$\% 20$ Coronavirus $\% 20$ and $\% 20$ its $\% 20$ impact $\% 20$ on $\% 20$ supply $\% 20$ chains $\% 20$ and $\% 20$ mobility $\% 20$ networks.pdf retrieved on 29 March 2020

${ }^{17}$ https://economictimes.indiatimes.com/wealth/borrow/rbis-loan-emi-moratorium-proposal-for-borrowers-heres-all-youneed-to-know/articleshow/74913557.cms retrieved on 30 March 2020

${ }^{18} \mathrm{https}$ ://economictimes.indiatimes.com/industry/transportation/roadways/covid-19-nhai-to-stop-collecting-toll-acrossnational-highways-during-lockdown/articleshow/74816787.cms?from=mdr retrieved on 30 March 2020
} 
The Indian Railways operates around 9,000 passenger trains and 3,500 mail express services each day. ${ }^{19}$ Due to corona virus at least $63 \%$ of the train ticket has been cancelled as stated by the senior railway ministry official in the meeting. ${ }^{20}$ As a protection against the Corona virus, Western and Central railways have removed all the curtains and blankets from the $\mathrm{AC}_{\text {coaches }}{ }^{21}$. The platform ticket price has also been increased from Rs 10 to Rs 50 across 250 stations ${ }^{22}$. Indian Railways has stopped functioning of all the trains amid Corona virus outbreak due to lockdown (expected till 14 ${ }^{\text {th }}$ April, 2020).

\subsubsection{Aviation}

In the near future, the demand for India's airline industry is expected to fall by $40-50 \%$. As per the Sydney-based CAPA Centre for Aviation, Indian airlines may ground 150 aircrafts. Much after the fall in price of oil, airlines will lose about $\$ 500$ million to $\$ 600$ million by the end of the quarter, barring Air India Ltd., which is as of now making losses. Without a genuine and significant Government mediation, such a result could prompt a few airlines closing down its activities by May or June because of lack of money. CAPA India said in a report. Most aircrafts should shrivel their operations and the more powerless transporters may shutdown id Government will not offer any monetary concessions and bolster offer. ${ }^{23}$

Due to travel restrictions as well as fall in demand among travellers, corona virus will have significant effect on the aviation industry. High reduction in traveller's number has bought about planes flying empty between airports and cancellation of flights. ${ }^{24}$ Every month across the country domestic air travel carries around 13 million passengers ${ }^{25}$. Legislature of India has reported that no global flights will be permitted to land in India from $22^{\text {nd }}$ March, 2020 amid corona virus pandemic. All the domestic flight has also been suspended starting $25^{\text {th }}$ March, $2020 .{ }^{26}$ Due to bans on travel in India, the global market will fall $70 \%$ and local by around half. Also, aircrafts should slice passages by almost $25 \%$ per kilometer and ground a larger part of their armada. ${ }^{27}$ India's carrier industry is especially powerless against any downturn and household booking also are down around 20 percent. Indigo - India's largest carrier has also seen a fall in traffic as much as $30 \%$ in India, while its universal flights have evaporated after government limitations on movement. It has grounded around 16 planes of its all out armada of 260 airplanes and is requesting that the representatives take 10-20 percent pay cuts.

Vistara will temporarily suspend all international flihts. The airlines has balanced its household limit and may make further changes with regards to March and April because of falling interest,. Go Airlines India Ltd. dropped a few household trips after suspending international routes. ${ }^{28}$ In India, GoAir and SpiceJet appear to be most in danger. SpiceJet,

\footnotetext{
${ }^{19}$ https://economictimes.indiatimes.com/industry/transportation/railways/government-mulls-curbing-train-travel-as-covid19-cases-rise-13000-trains-may-be-affected/printarticle/74756950.cms retrieved on 28 March 2020

${ }^{20} \mathrm{https}$ ://www.indiatoday.in/india/story/parliamentary-committee-reviews-impact-of-coronavirus-on-aviation-railways1657155-2020-03-18 retrieved on 30 March 2020

${ }^{21} \mathrm{https}$ ://www.business-standard.com/article/pti-stories/coronavirus-central-western-railway-withdraw-curtains-blanketsfrom-ac-coaches-120031401174_1.html Retrieved on 30 March 2020

${ }^{22}$ https://www.cnbctv18.com/healthcare/coronavirus-impact-railway-platform-ticket-price-hiked-to-rs-50-in-250-stations5501061.htm. Retrieved o n 26.03.2020

${ }^{23} \mathrm{https}$ ://simpleflying.com/coronavirus-indian-aviation-impact/ retrieved on $28 \mathrm{March} 2020$

${ }^{24}$ https://en.wikipedia.org/wiki/Impact of the 2019\%E2\%80\% 9320 coronavirus_pandemic on_aviation retrieved on 28 March 2020

${ }^{25}$ https://www.livemint.com/ retrieved on 29 March 2020

${ }^{26} \mathrm{https}$ ://www.livemint.com/news/india/coronavirus-india-suspends-domestic-flights-from-25-march11584962827845.html retrieved on 30 March 2020

${ }^{27} \mathrm{https} / / /$ simpleflying.com/coronavirus-indian-aviation-impact/ retrieved on $28 \mathrm{March} 2020$

${ }^{28} \mathrm{https}$ ://gulfnews.com/business/aviation/coronavirus-impact-indias-airlines-think-of-grounding-fleets-1.70492321 retrieved on 28 March 2020
} 
the second-biggest aircraft in India, is especially in danger, with a feeble accounting report and its share price falling about $75 \%$ from its high amount ${ }^{29}$.

Almost 585 global flights have been dropped to and from India between February 1 and March 6 due to the episode of corona infection. 16 worldwide aircrafts have dropped 492 flights and four private Indian carriers have dropped 93 trips during this period ${ }^{30}$.

Table 2: International Flights Cancelled to and from India between February 1 and March 6

\begin{tabular}{|l|l|}
\multicolumn{1}{|c|}{ Airlines } & \multicolumn{1}{c|}{$\begin{array}{c}\text { Number of Flight Cancelled } \\
\text { (to and from India) }\end{array}$} \\
\hline Malaysian carrier Malindo Air & 80 Flight \\
\hline Singapore-based Silk Air & 67 flights \\
\hline IndiGo (Weekly Basis) & 42 flights \\
\hline SpiceJet & 23 flights \\
\hline GoAir & 19 flights \\
\hline Full-service carrier Vistara & 9 flights \\
\hline $\begin{array}{l}\text { Sources: } \text { https://www.thehindubusinessline.com/news/coronavirus-impact- } \\
\text { over-580-flights-cancelled-to-and-from-india/article31051980.ece published on March 12, 2020 }\end{array}$ \\
\hline
\end{tabular}

The cancellations are likely to intensify as the Government suspended "all existing visas, except diplomatic, official, UN/international organisations, employment, and project visas" until April 15, 2020. The visa-free travel facility for Overseas Citizen of India (OCI) holders has been suspended. India forced these rigid travel checks after the World Health Organization (WHO) pronounced the crown infection episode a pandemic. ${ }^{31}$

Governments over the globe have given tourism warnings which have brought about a virtual shutdown of all our worldwide flights ${ }^{32}$

Table 3: Airlines Cancelled their Flight at Globally

\begin{tabular}{|l|l|}
\hline \multicolumn{1}{|c|}{ Airlines } & \multicolumn{1}{c|}{ Cancelled Flight } \\
\hline Air China & 16 flights \\
\hline Air Asia & 16 flights \\
\hline Bangkok Airways & 12 flights \\
\hline Cathay Dragon & 21 flights \\
\hline Cathay Pacific & 35 flights \\
\hline China Eastern Airlines & 56 flights \\
\hline China Southern & 28 flights \\
\hline Korean Air & 10 flights \\
\hline Malindo Air & 80 flights \\
\hline Silk Air & 67 flights \\
\hline Singapore Airlines & 36 flights \\
\hline Saudi Arabian Airline & 36 flights \\
\hline Thai Airways & 22 flights \\
\hline Thai Air Aisa & 35 flights \\
\hline Turkmenistan Airlines & 1 flight \\
\hline Thai lion & 20 flights \\
\hline
\end{tabular}

\footnotetext{
${ }^{29} \mathrm{https} / / /$ simpleflying.com/coronavirus-indian-aviation-impact/ retrieved on 28 March 2020

$30 \mathrm{https://www.thehindubusinessline.com/news/coronavirus-impact-over-580-flights-cancelled-to-and-from-}$ india/article31051980.ece published on March 12, 2020

${ }^{31} \mathrm{https} / / / \mathrm{www}$. thehindubusinessline.com/news/coronavirus-impact-over-580-flights-cancelled-to-and-fromindia/article31051980.ece published on March 12, 2020

${ }^{32} \mathrm{https}: / /$ gulfnews.com/business/aviation/coronavirus-impact-indias-airlines-think-of-grounding-fleets-1.70492321 retrieved on 28 March 2020
} 
Sources: https://www.thehindubusinessline.com/news/coronavirus-impact-over-

580-flights-cancelled-to-and-from-india/article31051980.ece published on March 12, 2020

\section{DISCUSSIONS}

Most of the Indian airlines has cut down there international routes while they have reduced their domestic operations. GoAir and Vistara have completely cut down their international flights while SpiceJet has also called off its handful of international routes. Even Indigo - which is the largest airline of the country has announced a $15 \%$ cut in the pay of all the staff. It has even cut down its $70 \%$ international flights. Air India has also withdrawn its cabin crew benefits by $30-40 \%$ and had also withdrawn benefits from its senior pilots. Air India has also cut all its European and Asian flights from significant urban areas and is been not able to pay salaries. AirAsia India, the endeavor among AirAsia and the Tata gathering, has declared it will quit growing its armada.

\section{CONCLUSIONS}

All types of Public transportations including Indian railway, Road Transport, International Ground Checks, Ship, Port and Aviation has stopped functioning due to lockdown. All public transport, railway stations, platforms, bus stops, Port and airport lounges have been routinely disinfected. As indicated by the Center For Aviation (CAPA), demand will fall half in the coming months. This will bring about most aircrafts crumbling in near future with no significant government intercession. The Indian government is to be sure during the time spent arranging a bailout bundle for aircrafts. This will probably incorporate an impermanent suspension of government-forced taxes and conceded instalment of charges, for example, fuel overcharges. On the off chance that the circumstance delays, aircrafts will probably require help as immediate funding to keep paying salaries and keeping their operations continue. The IATA has said the business will require almost $\$ 220 \mathrm{bn}$ to endure the corona infection storm. COVID-19 outbreak will continue impacting the Indian economy, trade and tourism.

\section{WEB REFERENCES}

1. https://www.cnbctv18.com/healthcare/coronavirus-impact-railway-platform-ticket-price-hiked-to-rs-50-in-250-stations5501061.htm. Retrieved o n 26.03.2020

2. https://www.livemint.com/news/india/coronavirus-india-suspends-domestic-flights-from-25-march-11584962827845.html retrieved on 30 March 2020

3. https://www.livemint.com/news/india/coronavirus-govt-can-spend-18-billion-to-fight-virus-impact-analysts-say11584949476261.html. Retrieved on 24 March 2020

4. https://economictimes.indiatimes.com/news/economy/indicators/moodys-slashes-india-gdp-growth-in-2020-to-25/articleshow/74840446.cms?from=mdr Retrieved on 28 March 2020

5. https://www.businessinsider.in/science/news/one-graphic-shows-how-long-the-coronavirus-lives-on-surfaces-like-cardboardplastic-and-steel/articleshow/74720814.cms last retrieved on 26.03 .2020

6. $\quad$ https://economictimes.indiatimes.com/industry/transportation/railways/government-mulls-curbing-train-travel-as-covid-19cases-rise-13000-trains-may-be-affected/printarticle/74756950.cms retrieved on 28 March 2020

7. https://economictimes.indiatimes.com/industry/transportation/roadways/covid-19-nhai-to-stop-collecting-toll-across-nationalhighways-during-lockdown/articleshow/74816787.cms?from=mdr retrieved on 30 March 2020 
8. https://economictimes.indiatimes.com/news/economy/foreign-trade/coronavirus-construction-transport-chemicalmanufacturing-likely-to-be-worst-affected-says-report/articleshow/74635122.cms last retrieved on 26.03.2020

9. http://www.fruitnet.com/eurofruit/article/181164/road-supply-chains-must-keep-moving retrieved on 26 March 2020

10. https://economictimes.indiatimes.com/news/economy/policy/covid-19-regularly-engaging-with-e-retailers-traders-to-ensuresmooth-supply-of-essential-goods-says-dpiit/printarticle/74846292.cms retrieved on 29 March 2020

11. https://economictimes.indiatimes.com/wealth/borrow/rbis-loan-emi-moratorium-proposal-for-borrowers-heres-all-you-needto-know/articleshow/74913557.cms retrieved on 30 March 2020

12. https://en.wikipedia.org/wiki/Impact of the 2019\%E2\%80\%9320 coronavirus pandemic on aviation retrieved on 28 March 2020

13. https://gulfnews.com/business/aviation/coronavirus-impact-indias-airlines-think-of-grounding-fleets-1.70492321 retrieved on 28 March 2020

14. https://qz.com/india/1819734/coronavirus-keeps-ola-uber-urban-company-on-toes-in-india/ retrieved on 30 March 2020

15. https://simpleflying.com/coronavirus-indian-aviation-impact/ retrieved on 28 March 2020

16. https://www.forbes.com/sites/timothypapandreou/2020/03/27/is-the-coronavirus-the-transportation-industrysopportunity/\#66fb0515752b last retrieved on 26.03.2020

17. https://www.health.harvard.edu/diseases-and-conditions/coronavirus-resource-center retrieved on 30 March 2020

18. https://www.indiatoday.in/india/story/parliamentary-committee-reviews-impact-of-coronavirus-on-aviation-railways1657155-2020-03-18 retrieved on 29 March 2020

19. https://www.iru.org/resources/newsroom/coronavirus-covid-19-iru-calls-governments-help-keep-road-transport-supplychains-and-mobility-networks-moving retrieved on 29 March 2020

20. https://www.iru.org/system/files/IRU\%20open\%20letter\%20\%20Coronavirus\%20and\%20its\%20impact\%20on\%20supply\%20chains\%20and\%20mobility\%20networks.pdf retrieved on 29 March 2020

21. https://www.jdsupra.com/legalnews/covid-19-impacts-to-transportation-12356/ retrieved on 28 March 2020

22. https://www.livemint.com/ retrieved on 29 March 2020

23. https://www.theguardian.com/world/2020/apr/01/what-is-coronavirus-and-what-is-the-mortality-rate-covid-19 retrieved 26 March 2020

24. https://www.thehindubusinessline.com/news/coronavirus-impact-over-580-flights-cancelled-to-and-fromindia/article31051980.ece published on March 12, 2020

25. https://www.uitp.org/sites/default/files/cck-focus-papers-files/Corona\%20Virus_EN.pdf retrieved on 27 March 2020

26. https://www.who.int/emergencies/diseases/novel-coronavirus-2019/advice-for-public retrieved on 26 March 2020

27. https://economictimes.indiatimes.com/news/economy/policy/india-inc-seeks-fiscal-stimulus-moratorium-on-debt-repayment-tomitigate-coronavirus-impact/articleshow/74759967.cms?from=mdr retrieved on 26 March 2020

28. https://economictimes.indiatimes.com/news/economy/policy/india-inc-seeks-fiscal-stimulus-moratorium-on-debt-repayment-tomitigate-coronavirus-impact/articleshow/74759967.cms?from=mdr retrieved on 26 March 2020

29. https://www.business-standard.com/article/pti-stories/coronavirus-central-western-railway-withdraw-curtains-blankets-from- 
ac-coaches-120031401174_1.html Retrieved on 30 March 2020

30. https://www.hindustantimes.com/india-news/nirmala-sitharaman-reviews-sectors-that-may-need-intervention/storyKhFNT5NejEDB4F3K8RPMOH.html retrieved on 25 March 2020

31. https://economictimes.indiatimes.com/markets/stocks/news/how-will-india-lockdown-play-out-for-economy-markets-4scenarios/articleshow/74804087.cms?from $=m d r$ Retrieved on 26 March 2020

32. https://www.thehindubusinessline.com/economy/experts-peg-indias-cost-of-coronavirus-lockdown-at-usd-120bn/article31160115.ece Retrieved on 25 March 2020

33. https://economictimes.indiatimes.com/news/economy/foreign-trade/coronavirus-construction-transport-chemicalmanufacturing-likely-to-be-worst-affected-says-report/articleshow/74635122.cms?from $=m$ dr last retrieved on 26.03.2020 
